\title{
CAUSES AND IMPLICATIONS OF THE CURRENT MASS EMIGRATION PROCESS IN LATIN AMERICA
}

\author{
DAVID KHOUDOUR-CASTÉRAS
}

Universidad Externado de Colombia.

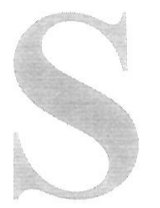

\section{ABSTRACT}

ince the mid-1970s, most Latin American countries have become net exporters of labour and this trend has accelerated over the past decade. Wide differences in income with industrialised countries, a low level of social investment and the existence of a large national community already established abroad are all factors that are conducive to the emigration of workers. Both geographic and linguistic proximity also play a significant role in this process. However, beyond the structural determinants, emigration also responds to short-term variations in economic activity, increasing when growth lags and unemployment rises, especially if economic conditions are strong in host countries. The linkage between migration flows and economic cycles is also reinforced by fixed exchange rates in the sending country, as labour mobility then acts as an adjustment mechanism.

Although the emigration of a portion of the labour force helps the short-term adjustment of Latin American economies by reducing labour market tensions and improving the current account balance, the longterm implications give great cause for concern. In particular, the massive influx of capital through remittances sent by migrant workers to their families might generate a "Dutch disease" situation detrimental to the development of the export sector, while the brain drain might curtail human capital accumulation in Latin America, thereby reducing the region's potential growth. Consequently, Latin American governments must take action in order to try to control a process that could compromise the region's economic and social future.

Keywords: emigration, labour forces, Latin America

"Economics and ethics are inseparable in the way we must consider international flows of humanity and seek to devise policies to manage them, enhancing the benefits and containing the problems that they entail." 


\section{INTRODUCTION}

Historically, Latin America is a land of immigration. However, since the mid-1970s, the majority of Latin American countries have become net exporters of labour and this trend has accelerated over the past decade. Thus, in the 1990s, some six million Latin Americans left their countries to try their luck abroad. The vast majority of them went to the United States. Because of the lack of economic opportunities and the absence of welfare states worthy of the name, a growing number of more or less skilled workers have been compelled to emigrate far from home. Although this trend is very similar to the mass migrations of Europeans before the First World War, it does give cause for concern. Neither the absorption capacity of labour markets in industrialised countries nor the attitudes of their policy-makers are comparable to the situation prevailing in the "New World" in the 19th century. With few exceptions, the most significant of which is Spain, the majority of countries in the North, faced with problems of structural unemployment and a public opinion that is mostly hostile to open borders, are seeking to limit migration flows from the South as far as possible. Since at the same time the pressure to emigrate continues to grow, there is an expansion of illegal immigration which makes it difficult for immigrants to be integrated into their host country. Above all, an important emigration of skilled workers would likely pose problems for the economic and social development of Latin America.

Although the emigration of a portion of the labour force helps the short-term adjustment of Latin American economies by reducing labour market tensions and improving the current account balance, the longterm implications give great cause for concern. In particular, the massive influx of capital through remittances sent by migrant workers to their families might generate a "Dutch disease" situation detrimental to the development of the export sector, while the brain drain might curtail human capital accumulation in Latin America, thereby reducing the region's potential growth. Consequently, Latin American governments must take action in order to try to control a process that could compromise the region's economic and social future.

\section{WHY DO LATIN AMERICANS EMIGRATE?}

Latin America's troubled political situation has been partly responsible for the development of migration movements. The many coups that took place in the region until the late 1980s and the ensuing periods of repression led to population shifts, especially to neighbouring 
countries. In this regard, the persecution of opponents of the Pinochet regime after the 1973 coup explains why many Chileans were living abroad in the 1980s. The civil wars in Central America during the 1970 s and 1980s also triggered a rise in immigration from Nicaragua, El Salvador and Guatemala to Mexico and Costa Rica. Similarly, the armed conflict in Colombia, which has intensified during the past decade, has led to major emigration by populations fleeing the violence in their country'. Despite these problems, the causes of the current mass emigration process in Latin America are above all economic.

\subsection{Latin American emigration primarily reflects structural trends}

The wide income differential between Latin America and the industrial countries of the North (Table 1) is a key determinant of emigration. It is only because would-be emigrants know that they can improve their living standards significantly that they are willing to undertake a journey that is costly not only in economic terms (the cost of travelling to a foreign country and establishing themselves, finding a job and paying intermediaries, such as "coyotes", when crossing borders illegally), but also in psychological terms (adapting to a new country, new culture and sometimes a new language).

Table 1: GDP per capita in $\mathbf{2 0 0 3}$

\begin{tabular}{|l|c|}
\hline REGION & GDP IN DOLLARS \\
\hline United States & 37,388 \\
\hline Euro Zone & 26,704 \\
\hline Latin America and Caribbean & 3,246 \\
\hline
\end{tabular}

Source: World Bank (2005).

However, differences in living standards alone cannot account for the magnitude of emigration movements in Latin America. Table 2 shows the emigration rate to the United States $^{2}$ and per capita GDP for 31 countries of Latin America and the Caribbean. Firstly, it is important to point out that the correlation coefficient between the two variables

1 There are two main reasons why violence leads to an increase in emigration. Firstly, because of clashes between the various armed participants in the conflict (guerrillas, the armed forces and paramilitary groups), the civil population, especially farmers, flee combat zones and try to find refuge either in the principal cities or abroad. The threats that many Colombian families receive from the various belligerent groups or from criminals also force many of them into exile in order to escape from their persecutors. This latent civil war also has a considerable economic cost, which the Colombian National Planning Department estimates at approximately $4 \%$ of GDP (1998). As a result, Colombians suffer indirectly from political violence because of the economic crisis and unemployment that it generates.

2 The emigration rate reflects the number of official immigrants into the United States in relation to the country's population, multiplied by 1000 . It therefore does not take into account emigration to the rest of the world (nor to the countries within the region), or illegal migration. However, as the United States is the main receiving country (some $90 \%$ of Latin American emigration), it provides a relatively good approximation of the actual emigration rate. 
Table 2. Emigration rate, GDP per capita and social expenditures: 1980-2001

\begin{tabular}{|c|c|c|c|}
\hline PAYS & $\begin{array}{c}\text { EMIGRATION RATE } \\
(\%)\end{array}$ & $\begin{array}{l}\text { GDP PER CAPITA } \\
\text { (in dollars) }\end{array}$ & $\begin{array}{c}\text { SOCIAL EXPENDITURES/ } \\
\text { PIB }(\%)\end{array}$ \\
\hline Mexico & 2.22 & 4223 & 8.16 \\
\hline \multicolumn{4}{|c|}{ CENTRAL AMERICA } \\
\hline Belize & 7.42 & 2123 & \\
\hline Costa Rica & 0.48 & 3121 & 16.15 \\
\hline El Salvador & 4.01 & 1534 & 3.75 \\
\hline Guatemala & 1.03 & 1438 & 4.36 \\
\hline Honduras & 1.13 & 702 & 7.73 \\
\hline Nicaragua & 1.74 & 521 & 11.52 \\
\hline Panama & 1.13 & 2883 & 19.60 \\
\hline \multicolumn{4}{|c|}{ SOUTH AMERICA } \\
\hline Argentina & 0.08 & 6678 & 19.62 \\
\hline Bolivia & 0.21 & 893 & 14.74 \\
\hline Brazil & 0.03 & 4005 & 19.29 \\
\hline Chile & 0.16 & 4099 & 14.09 \\
\hline Colombia & 0.36 & 2131 & 11.80 \\
\hline Equator & 0.65 & 1527 & \\
\hline Guyana & 11.32 & 560 & \\
\hline Paraguay & 0.09 & 1672 & 6.30 \\
\hline Peru & 0.38 & 2282 & 5.35 \\
\hline Uruguay & 0.22 & 5071 & 19.91 \\
\hline Venezuela & 0.12 & 3243 & 8.46 \\
\hline \multicolumn{4}{|c|}{ CARIBBEAN } \\
\hline Antigua-et-Barbuda & 13.56 & 5801 & \\
\hline Barbados & 5.42 & 6140 & \\
\hline Cuba & 1.64 & 3580 & \\
\hline Dominique & 7.97 & 2687 & \\
\hline Grenada & 10.51 & 2271 & \\
\hline Haiti & 2.28 & 498 & \\
\hline Jamaica & 8.11 & 1918 & \\
\hline Dominican Republic & 4.03 & 1536 & 5.76 \\
\hline Saint Kitts and Nevis & 17.89 & 3991 & \\
\hline Saint Vincent and the Grenadines & 6.04 & 1734 & \\
\hline Saint Lucia & 4.80 & 2212 & \\
\hline Trinity and Tobago & 4.27 & 5122 & \\
\hline
\end{tabular}

Notes: Emigration rate $=($ immigrants in the United States/population $) \times 1000$. Social expenditures include public expenditures for education, health, social security and housing. They are stated in percentage of the GDP.

Sources: Emigration rate: calculations of the author based on the U.S. Department of Homeland Security (several years); GDP per capita and social expenditures: CEPAL (2005).

for the entire zone is positive, but not very significant (0.08). If the Caribbean countries are excluded, the correlation coefficient becomes -0.37 , i.e. it is negative and slightly significant. There are a number of factors that can explain the absence of a strong negative correlation between per capita GDP and the emigration rate. Firstly, the emigration rate is linked to the distance between the sending and the host country. The geographic proximity of Mexico and the Central American countries to the United States explains the higher emigration rate in the 
region. On the other hand, the fact that the countries in the Southern hemisphere are distant probably tends to lower the emigration rate in that region. English-speaking countries also generally have a higher rate of emigration to the United States than the other countries of the region. Belize and Guyana illustrate this very clearly, since they are the only two English-speaking countries in Central and South America and they have significantly higher emigration rates than their neighbours. Similarly, it seems logical that Spain has become one of the main host countries for Latin American migrants in Europe (CEPAL, 2002). In addition to its relatively favourable policy regarding immigration, Spain offers nationals of its former colonies the benefit of having the same language.

Although per capita income levels cannot explain the differences in migration behaviour across Latin American countries, government social policies could be a key determinant in the emigration process. In fact, public services in the field of education and health care, sickness and work accident insurance, unemployment benefits and retirement pensions represent a form of "indirect salary" that supplements income from work (Khoudour-Castéras, 2005). Would-be emigrants take this indirect salary into account in calculating their anticipated income. If they are risk-adverse, which is most likely, they even tend to give relatively greater weight to the different forms of "social remuneration" than to direct income from work. Chart 1 shows the relationship between social expenditure as a percentage of GDP and the emigration rate for 17 Latin American countries between 1990 and 1999. While there is a correlation between investments in the social sector and the emigration rate towards United States, it does not seem to be very strong. Argentina, Brazil, Costa Rica and Uruguay, which devote a relatively large share of their GDP to social expenditure, have an average emigration rate that is much lower than that of the other countries of the region. On the other hand, countries such as the Dominican Republic, El Salvador and Mexico, where social expenditure is lower than the regional average, have high emigration rates. But there are also many countries, where the emigration rate is low and the social expenditure varies from 4 to 15 per cent of the GDP.

There is also a barrier to emigration that is related to the poverty of the countries considered, since would-be emigrants must have a certain initial income in order to immigrate to a foreign country (Hatton and Williamson, 1998). It is therefore not surprising that the region's poorest countries are not necessarily those with the highest emigration rate. Thus Bolivia in South America, Honduras in Central America and Haiti in the Caribbean have lower emigration rates than many of their 
richer neighbours. Nevertheless, the poverty effect can be mitigated by mechanisms of solidarity between family members, friends and neighbours, since an important factor in labour mobility is the practice of "chain migration", i.e. when initial emigrants begin to be successful, they act as a bridgehead for the other members of the community, not only by contributing financial aid to pay travel costs, but also by providing first-hand information on labour market conditions, helping with administrative formalities, in particular to obtain a visa, and by housing new immigrants. It is therefore not surprising that migration flows are associated with the presence of national communities in receiving countries. In this regard, Latin American emigration to the United States is marked by a strong historical continuity (Clark, Hatton and Williamson, 2003).

Table 3 shows the cities in the United States, to which new Latin American immigrants went in 2003, indicating where the main Latin American communities in the United States are located. In general, Los Angeles, New York and Miami ranked first. However, each nationality

Table 3. Destination of main immigrant groups in the United States in 2003

\begin{tabular}{|c|c|c|c|c|c|}
\hline \multirow{2}{*}{$\begin{array}{l}\text { ORIGIN COUNTRY } \\
\text { Mexico }\end{array}$} & \multirow{2}{*}{\begin{tabular}{|c|} 
TOTAL \\
NUMBER OF \\
IMMIGRANTS \\
115585
\end{tabular}} & \multicolumn{3}{|c|}{$\begin{array}{l}\text { MAIN DESTINATION TOWNS } \\
\text { (\% IN EACH TOWN) }\end{array}$} & \multirow{2}{*}{$\begin{array}{c}\text { \% IN THE } \\
\text { 3 MAIN } \\
\text { TOWNS } \\
23.7\end{array}$} \\
\hline & & $\begin{array}{l}\text { Los Angeles } \\
\quad(14.2)\end{array}$ & $\begin{array}{c}\text { Chicago } \\
(4.9)\end{array}$ & $\begin{array}{c}\text { San Diego } \\
(4.6)\end{array}$ & \\
\hline EI Salvador & 28231 & $\begin{array}{l}\text { Los Angeles } \\
\quad(35.9)\end{array}$ & $\begin{array}{l}\text { Washington } \\
\quad(11.4)\end{array}$ & $\begin{array}{c}\text { Nassau-Suffolk } \\
(10.6)\end{array}$ & 57.9 \\
\hline $\begin{array}{l}\text { Dominican } \\
\text { Républic }\end{array}$ & 26159 & $\begin{array}{l}\text { Los Angeles } \\
\quad(47.8)\end{array}$ & $\begin{array}{l}\text { San Juan } \\
(7.9)\end{array}$ & $\begin{array}{c}\text { Bergen-Passaic } \\
(5.5)\end{array}$ & 61.1 \\
\hline Colombia & 14720 & $\begin{array}{l}\text { Miami } \\
(18.0)\end{array}$ & $\begin{array}{l}\text { New York } \\
(11.2)\end{array}$ & $\begin{array}{l}\text { Fort Lauderdale } \\
\qquad(8.1)\end{array}$ & 37.3 \\
\hline Guatemala & 14386 & $\begin{array}{c}\text { Los Angeles } \\
(36.7)\end{array}$ & $\begin{array}{c}\text { Washington } \\
(3.8)\end{array}$ & $\begin{array}{c}\text { New York } \\
(3.4)\end{array}$ & 43.9 \\
\hline Jamaica & 13347 & $\begin{array}{c}\text { New York } \\
(31.4)\end{array}$ & $\begin{array}{c}\text { Fort Lauderdale } \\
(14.3)\end{array}$ & $\begin{array}{c}\text { Miami } \\
(6.6)\end{array}$ & 52.3 \\
\hline Haiti & 12293 & $\begin{array}{c}\text { New York } \\
(20.3)\end{array}$ & $\begin{array}{l}\text { Miami } \\
(15.2)\end{array}$ & $\begin{array}{l}\text { Fort Lauderdale } \\
\qquad(10.6)\end{array}$ & 46.1 \\
\hline Peru & 9409 & $\begin{array}{c}\text { Miami } \\
(18.0)\end{array}$ & $\begin{array}{c}\text { Washington } \\
(9.0)\end{array}$ & $\begin{array}{c}\text { New York } \\
(7.4)\end{array}$ & 34.4 \\
\hline Cuba & 9262 & $\begin{array}{l}\text { Miami } \\
(57.0)\end{array}$ & $\begin{array}{l}\text { Tampa } \\
(2.9)\end{array}$ & $\begin{array}{c}\text { Las Vegas } \\
(2.8)\end{array}$ & 62.7 \\
\hline Equator & 7066 & $\begin{array}{l}\text { New York } \\
(36.6)\end{array}$ & $\begin{array}{c}\text { Newark } \\
(7.4)\end{array}$ & $\begin{array}{c}\text { Nassau-Suffolk } \\
\text { (7.1) }\end{array}$ & 51.1 \\
\hline Guyana & 6809 & $\begin{array}{c}\text { New York } \\
(64.1)\end{array}$ & $\begin{array}{c}\text { Newark } \\
(5.9)\end{array}$ & $\begin{array}{c}\text { Jersey City } \\
(3.1)\end{array}$ & 73.1 \\
\hline Brazil & 6331 & $\begin{array}{l}\text { Boston } \\
(10.4)\end{array}$ & $\begin{array}{l}\text { Fort Lauderdale } \\
\qquad(7.5)\end{array}$ & $\begin{array}{c}\text { Miami } \\
(7.1)\end{array}$ & 25.0 \\
\hline Latin America & 293608 & $\begin{array}{l}\text { Los Angeles } \\
\quad(12.3)\end{array}$ & $\begin{array}{c}\text { New York } \\
(12.2)\end{array}$ & $\begin{array}{l}\text { Miami } \\
(6.5)\end{array}$ & 31.0 \\
\hline Total immigration & 703542 & $\begin{array}{l}\text { New York } \\
(10.2)\end{array}$ & $\begin{array}{c}\text { Los Angeles } \\
(9.2)\end{array}$ & $\begin{array}{c}\text { Chicago } \\
(4.2)\end{array}$ & 23.6 \\
\hline
\end{tabular}

Source: Calculations of the author based on the U.S. Department of Homeland Security (2004). 
has specific characteristics that show the network effects mentioned earlier. Guyanese primarily go to New York (64.1\%), Cubans to Miami (57\%) and Dominicans to Los Angeles (47.8\%), while Brazilians are mainly concentrated in Boston (10.4\%). It is also interesting to note that a sizeable share of Mexicans went to Chicago (4.9\%), thus swelling the ranks of the Mexican community already settled in Illinois. In fact, the chain migration process tends to raise the level of migration beyond what the traditional determinants would suggest. In this regard, it is possible to speak of a hysteresis effect in international migration, for even if the initial causes of migration movements have disappeared, the mere fact that members of the community are established abroad encourages continued emigration.

\section{EMIGRATION ALSO RESPONDS TO VARIATIONS IN ECO- NOMIC ACTIVITY}

Table 4 shows the correlation coefficients between the relative change in the emigration rate and a number of indicators of the economic situation: the GDP growth, the relative change in the unemployment and in the exchange rates. The results cover 31 countries in Latin America and the Caribbean over the 1990-2003 period. There is a one-year lag between the indicators (year $\mathrm{t}-1$ ) and the emigration rate (year $\mathrm{t}$ ). This corresponds to the time required for would-be migrants to make their decision and organise their departure. The first two columns show the correlation with domestic GDP growth and unemployment rates. In most cases, the relative change in the emigration rate is negatively correlated to the GDP growth rate and positively correlated to the relative change in the unemployment rate. In other words, a slowdown in economic activity, combined with a rise in the unemployment rate, generally leads to an increase in the number of departures. For example, in Argentina, the decline in GDP $(-3.4 \%)$ and the rise in the unemployment rate $(+10.9 \%)$ in 1999 were followed by a $65.6 \%$ increase in the emigration rate in 2000. Similarly, in Brazil, the fall in GDP (-4.6\%) and the rise in the unemployment rate $(+26.5 \%)$ in 1990 led to an increase in emigration rate $(+90.8 \%)$. On the other hand, the strong growth of the Brazilian economy in $1994(+6.2 \%)$ resulted in a significant decline in the emigration rate $(-4 \%)$.

The third and fourth columns of Table 4 show the correlation between variations in the GDP growth rate as well as the relative change in the unemployment rate (year t-1) of the United States and that of the emigration rate (year $t$ ). In this case, the correlation is positive for GDP and negative for unemployment, i.e. economic expansion in the United 
Table 4. Correlations between emigration rate relative variation and economic situation indicators: $1990-2003$

\begin{tabular}{|c|c|c|c|c|c|}
\hline COUNTRY & $\begin{array}{c}\text { DOMESTIC } \\
\text { GDP }\end{array}$ & \begin{tabular}{|} 
DOMESTIC \\
UNEMPLOYMENT
\end{tabular} & $\begin{array}{l}\text { AMERICAN } \\
\text { GDP }\end{array}$ & $\begin{array}{l}\text { AMERICAN } \\
\text { UNEMPLOYMENT }\end{array}$ & $\begin{array}{l}\text { EXCHANGE } \\
\text { RATE }\end{array}$ \\
\hline Mexico & -0.39 & 0.40 & 0.47 & -0.53 & -0.03 \\
\hline \multicolumn{6}{|c|}{ CENTRAL AMERICA } \\
\hline Belize & 0.19 & & 0.62 & -0.48 & \\
\hline Costa Rica & -0.66 & 0.31 & 0.43 & -0.44 & -0.30 \\
\hline El Salvador & -0.61 & 0.50 & 0.45 & -0.30 & -0.30 \\
\hline Guatemala & -0.69 & 0.60 & 0.51 & -0.30 & -0.25 \\
\hline Honduras & -0.23 & 0.51 & 0.51 & -0.39 & -0.05 \\
\hline Nicaragua & 0.27 & -0.42 & 0.36 & -0.42 & -0.01 \\
\hline Panama & -0.53 & 0.45 & 0.55 & -0.47 & \\
\hline \multicolumn{6}{|c|}{ SOUTH AMERICA } \\
\hline Argentina & -0.43 & 0.31 & 0.14 & -0.14 & -0.30 \\
\hline Bolivia & -0.30 & 0.35 & 0.47 & -0.54 & -0.34 \\
\hline Brazill & -0.36 & -0.29 & 0.18 & -0.33 & -0.13 \\
\hline Chile & -0.34 & 0.56 & 0.51 & -0.47 & -0.19 \\
\hline Collombia & -0.33 & 0.22 & 0.43 & -0.39 & -0.19 \\
\hline Equator & -0.33 & -0.06 & 0.48 & -0.47 & 0.14 \\
\hline Guyana & -0.26 & & 0.16 & -0.20 & -0.14 \\
\hline Paraguay & 0.11 & -0.05 & 0.17 & -0.20 & -0.22 \\
\hline Peru & -0.37 & 0.23 & 0.26 & -0.34 & 0.03 \\
\hline Uruguay & -0.48 & 0.51 & 0.36 & -0.34 & -0.53 \\
\hline Venezuela & -0.18 & 0.47 & 0.33 & -0.31 & -0.25 \\
\hline \multicolumn{6}{|c|}{ CARIBBEAN } \\
\hline Antigua-et-Barbuda & -0.10 & & 0.56 & -0.46 & \\
\hline Barbados & 0.20 & & 0.36 & -0.41 & \\
\hline Cuba & 0.07 & 0.47 & 0.09 & -0.33 & \\
\hline Dominique & -0.42 & & -0.11 & 0.18 & \\
\hline Grenada & 0.22 & & 0.28 & -0.32 & \\
\hline Haiti & 0.04 & & 0.23 & -0.46 & -0.39 \\
\hline Jamaica & 0.16 & 0.29 & 0.40 & -0.46 & -0.45 \\
\hline Dominican Republic & -0.78 & 0.46 & -0.36 & 0.43 & 0.06 \\
\hline Saint Kitts and Nevis & 0.15 & & 0.69 & -0.57 & \\
\hline Saint Vincent and the Grenadines & -0.30 & & 0.16 & -0.31 & \\
\hline Saint Lucia & -0.18 & & 0.34 & -0.40 & \\
\hline Trinity and Tobago & 0.23 & 0.57 & 0.12 & -0.33 & -0.14 \\
\hline
\end{tabular}

Notes: Correlation coefficient refers to the relation between the emigration rate relative variation (year $\mathrm{t}$ ) and each of the variables mentioned on top of column (year $\mathrm{t}-1$ ).

Sources: Emigration rate: calculations of the author based on the U.S. Department of Homeland Security (several years); GDP and unemployment rates in Latin America: CEPAL (2005); GDP and unemployment rate in the United States and exchange rate: IMF (several years).

States, the foremost host country for Latin American emigrants, logically leads to a rise in emigration rates in Latin America. For example, it is striking to observe that the sharp increase in unemployment in the United States in $1991(+23.2 \%)$ led to a decrease in emigration to this country in virtually all Latin American countries (-77.8\% in Mexico, $-77.3 \%$ in Haiti, $-59.7 \%$ in Guatemala, $-51.1 \%$ in Nicaragua and - 
$50.9 \%$ in Bolivia). In sum, would-be emigrants go more readily to the United States when growth there is strong and unemployment low and when economic activity is slow in their own country. This means that if domestic economic cycles are correlated to those of the United States, the fluctuations in emigration rates are less strong than if the cycles are not synchronised.

The last column of Table 4 shows the relation between relative variations in the exchange rate (year t-1) and the emigration rate (year t). There is a negative, although weak, correlation between the exchange and the emigration rates. There are three main explanations for this occurrence, which is analysed in detail by Sánchez-Alonso (2000). Firstly, the depreciation of currencies leads to an increase in transport costs, as airline tickets are generally denominated in dollars. Next, the increase in the exchange rate reduces the external value of domestic savings, thereby decreasing the resources of would-be emigrants and reducing their possibilities of moving abroad. Lastly, the depreciation improves the competitiveness of exporting companies and therefore has a favourable impact on employment, thus reducing the number of potential migrants.

In this regard, it is likely that the prevailing exchange rate regime influences migration behaviour, in particular the linkage between economic activity and the emigration rate. For example, the adoption of fixed exchange rate regimes with narrow fluctuation band mechanisms, as in Colombia and Venezuela, of a currency board as in Argentina, and even of the total dollarisation of economies as in Ecuador and El Salvador, partially contributed to the rise in emigration in the region. This was because the constraints imposed by pegging the currency to the dollar hurt the competitiveness of the export sector and led to large balance of payment disequilibria. International migrations were then able to play an adjustment mechanism role in countries that had lost their exchange rate instrument. However, the abandonment of fixed parities in most countries in the region (Mexico in 1995, Colombia and Chile in 1998, Brazil in 1999, Argentina in 2001, etc.) did not end the role of safety valve played by migration, for the exchange rate instability that followed led to a crisis of confidence among international investors, which was detrimental to adjustment through capital mobility. Ultimately, it is likely that the countries that have successfully made the transition to a flexible exchange rate regime will see a reduction in the link between emigration and economic activity, while those that have chosen to peg their currencies to the dollar, such as Ecuador and El Salvador, will see this link become stronger. 
Lastly, the process of liberalisation of Latin American economies that followed the debt crisis of the 1980s certainly also contributed to strengthening the link between economic activity and emigration, since the opening up to trade of economies that had until then been strongly protected led to a weakening of the industrial fabric and a sharp rise in unemployment, particularly among the least skilled members of the labour force. International migration then acted as a substitute for the virtually non-existent unemployment benefits in the region.

\section{EMIGRATION: A BOON OR A BANE FOR LATIN AMERICA?}

\subsection{International migrations contribute to the short-term equilibrium of Latin American economies}

International labour mobility acts as an adjustment mechanism both internally, by lowering the unemployment rate in sending countries and by reducing inflationary pressures in host countries, as well as externally, by facilitating the return to a balanced current account (Khoudour-Castéras, 2004). The departure of a portion of the labour force lessens competition on the labour market of emigration countries, which reduces unemployment. Conversely, the arrival of immigrants leads to greater competition on the labour market of the host country, which makes it possible to limit wage increases and thereby combat inflation when the economy is overheating. With regard to external equilibrium, there are two main channels of transmission. Firstly, outflows of labour lead to lower demand and consequently lower imports in sending countries, although other factors could bend or even reverse these impacts on aggregate level. In immigration countries, on the other hand, there is an increase in domestic demand and thus in imports because of the arrival of new workers. If the sending and host countries are also trading partners, the direct effect on current accounts of variations in imports could be reinforced by the increase in exports in emigration countries and their decline in immigration countries (the latter's imports are the former's exports). The other channel of transmission is constituted by the remittances that migrants send to their families in their home country. These remittances are entered into the current account balance (invisibles balance) and remittances from immigration countries to emigration countries, and would mechanically contribute to a rebalancing of current accounts.

Table 5 shows the correlation coefficient between the relative change in the emigration rate (year t-1) and that of the current account (year t) for 32 Latin American countries between 1990 and 2003. On 
Table 5. Emigration rate and current account: 1990-2003

\begin{tabular}{|c|c|}
\hline COUNTRY & CORRELATION COEFFICIENT \\
\hline Mexico & 0.55 \\
\hline \multicolumn{2}{|c|}{ CENTRAL AMERICA } \\
\hline Belize & 0.30 \\
\hline Costa Rica & -0.24 \\
\hline EI Salvador & -0.29 \\
\hline Guatemala & -0.20 \\
\hline Honduras & 0.45 \\
\hline Nicaragua & 0.24 \\
\hline Panama & 0.17 \\
\hline \multicolumn{2}{|c|}{ SOUTH AMERICA } \\
\hline Argentina & -0.45 \\
\hline Bolivia & 0.07 \\
\hline Brazil & 0.12 \\
\hline Chile & -0.17 \\
\hline Colombia & 0.45 \\
\hline Equator & 0.15 \\
\hline Guyana & 0.28 \\
\hline Paraguay & -0.34 \\
\hline Peru & 0.34 \\
\hline Uruguay & -0.39 \\
\hline Venezuela & 0.82 \\
\hline \multicolumn{2}{|c|}{ CARIBBEAN } \\
\hline Antigua-et-Barbuda & 0.14 \\
\hline Barbados & 0.27 \\
\hline Cuba & \\
\hline Dominique & 0.27 \\
\hline Grenada & 0.47 \\
\hline Haiti & 0.65 \\
\hline Jamaica & 0.71 \\
\hline Dominican Republic & -0.32 \\
\hline Saint Kitts and Nevis & 0.21 \\
\hline Saint Vincent and the Grenadines & 0.67 \\
\hline Saint Lucia & 0.39 \\
\hline Trinity and Tobago & 0.39 \\
\hline
\end{tabular}

Notes: Correlation coefficient refers to the relation between the emigration rate growth rate (year $t-1$ ) and the current account growth rate (year $t$ ).

Sources: Emigration rate: calculs of the author based on the U.S. Department of Homeland Security (several years); current account: IMF (2005).

the whole, the correlation coefficient is positive, which supports the idea that an increase in the emigration rate leads to improvement in the current account. The countries for which the relation is most significant are Venezuela (0.82), Jamaica (0.71), Saint Vincent and the Grenadines (0.67), Haiti (0.65) and Mexico (0.55). However, the relation is not positive for all Latin American countries. Some of them, particularly in Central America, show a negative correlation. This can be explained by the fact that, in some cases, emigration tends to increase trade 
Table 6. Migrants' remittances: 1990 and 2003

\begin{tabular}{|c|c|c|c|c|c|c|c|}
\hline \multirow{2}{*}{ COUNTRY } & \multicolumn{2}{|c|}{ REMITTANCES } & \multirow{2}{*}{$\begin{array}{l}\text { ANNUALAVERAGE } \\
\text { GROWTH RATE (\%) }\end{array}$} & \multicolumn{2}{|c|}{$\%$ OF GDP } & \multicolumn{2}{|c|}{$\%$ OF EXPORTS } \\
\hline & 1990 & 2003 & & 1990 & 2003 & 1990 & 2003 \\
\hline Mexico & 2492 & 13266 & 13.7 & 0.9 & 2.1 & 6.1 & 8.0 \\
\hline Colombia & 486 & 3060 & 15.2 & 1.2 & 3.9 & 6.6 & 21.1 \\
\hline Guatemala & 107 & 2107 & 25.8 & 1.4 & 8.5 & 7.0 & 49.3 \\
\hline El Salvador & 357 & 2105 & 14.6 & 7.9 & 14.1 & 36.7 & 48.4 \\
\hline Dominican Republic & 315 & 2060 & 15.5 & 4.5 & 9.2 & 21.9 & 30.2 \\
\hline Brazil & 527 & 2018 & 10.9 & 0.1 & 0.4 & 1.7 & 2.7 \\
\hline Equator & 50 & 1539 & 30.2 & 0.5 & 5.7 & 1.6 & 21.6 \\
\hline Jamaica & 136 & 1270 & 18.8 & 3.2 & 19.2 & 6.1 & 39.3 \\
\hline Honduras & 50 & 860 & 24.5 & 1.6 & 12.4 & 4.1 & 25.2 \\
\hline Peru & 87 & 860 & 19.3 & 0.2 & 1.3 & 2.2 & 8.5 \\
\hline Haiti & - & 811 & - & - & 29.1 & - & 49.3 \\
\hline Nicaragua & 10 & 439 & 33.8 & 0.9 & 10.6 & 1.2 & 21.3 \\
\hline Costa Rica & - & 306 & - & - & 1.8 & - & 4.4 \\
\hline Argentina & - & 236 & - & - & 0.3 & - & 0.8 \\
\hline Latin America & 4751 & 31569 & 15.7 & 0.4 & 1.6 & 3.0 & 7.9 \\
\hline
\end{tabular}

Note: Remittances and foreign direct investment (FDI) are stated in current millions dollars. Exports contain goods and services.

Source: IMF (2005).

deficits because of strong demand for imported goods stimulated by consumption patterns. Generally speaking, moreover, the repercussions of remittances on the economies of emigration countries are far from simple.

\subsection{Remittances: a risk of "Dutch disease"}

Standing at $\$ 31.6$ billion in 2003 (roughly one-third of the total remittances sent to developing countries), the remittances of emigrant workers are a major source of currency for Latin American countries (Table 6). The main receiving countries are Mexico ( $\$ 13.3$ billion), Colombia ( $\$ 3.1$ billion) and Guatemala and El Salvador ( $\$ 2.1$ billion each). These remittances sometimes account for a significant share of national production (29.1\% of GDP for Haiti, 19.2\% for Jamaica and $14.1 \%$ for El Salvador) and especially of the current account balance (half of the exports of Guatemala, Haiti and El Salvador). What is more, the amount of remittances is often larger than that of foreign direct investment and, more especially, of official development assistance. Chart 2 shows the comparative trend of official development assistance, foreign direct investment and remittances in Latin America between 1990 and 2003. While in 1990 , remittances ranked last $(\$ 4.8$ billion as compared with $\$ 5$ billion for official development assistance and $\$ 8.4$ billion for foreign direct investment), they now rank first ( $\$ 31.6$ billion as compared with $\$ 5.1$ billion for official development assistance and \$28.4 billion for foreign direct investment). Even though 
2003 was a particularly poor year for foreign investment, this trend shows the growing weight of remittances in Latin American economies. Furthermore, these figures only cover the "official" remittances sent through banks and other financial intermediaries. The fact is that a large share of remittances does not go through official channels, which are often costly, and it is the migrants themselves, or family members or friends, who carry the money when they travel home. As a result, the magnitude of remittances is in reality considerably underestimated.

The families that have remained at home are the main beneficiaries of the windfall represented by the remittances sent by emigrants. This influx of money is all the more important to these families given that they are most often living in precarious circumstances and sometimes even in conditions of extreme poverty, particularly in Central American and Caribbean countries. For example, a survey conducted in Honduras in 1997 showed that $83 \%$ of households receiving remittances were below the poverty threshold (Perdomo, 2001). This financial contribution thus helps to support consumption in receiving countries, even though this generally involves essential goods, especially food. In Ecuador, for example, the share of remittances used for food, rent and medicine is estimated at $80 \%$ (CEPAL, 2004). The money sent by migrants, which is one of the main sources of savings in many Latin American countries, is also used in some cases to create micro-businesses. These are usually small businesses operating in the informal economy, but which enable families to generate extra income. In addition to personal remittances, Latin American emigrants have also started many associations both in the United States and Europe aimed at financing social and infrastructure projects in their home neighbourhoods or villages. In this way, these organisations fill the gaps in public service provision in Latin American countries.

However, remittances also pose a number of problems for receiving countries. Firstly, they create a state of dependency that is detrimental to the dynamism of local economic activity. Families, and sometimes whole villages, survive by means of these outside contributions which are not, however, transformed into productive investments. The influx of capital also causes the national currency to appreciate, which creates problems in terms of the competitiveness of domestic tradable goods. This causes activity to shift toward the sector of non-tradable goods, which are also those for which domestic demand is greatest. As a result, economies that are highly dependent on remittances may find themselves in a situation much like the "Dutch disease". To prevent this kind of effect, the monetary authorities tend to devaluate their currency regularly, which also enables them to attract the savings of emigrants. 
However, the loss of value of the national currency creates inflationary pressures and discourages foreign investment. It was partly in order to escape from the dilemma of alternating between an overvalued currency and devaluation that El Salvador decided to dollarise its economy in 2001. This decision also shows the extent to which El Salvador, together with many other countries in the region, is now highly dependent on the U.S. economy.

\subsection{The brain drain: a risk of a negative externality in terms of human capital}

The majority of Latin American emigrants are unskilled workers. According to CELADE (2002), only 5\% of Latin Americans who emigrated to Canada and the United States between 1988 and 1995 were skilled workers (university graduates and technical workers). Moreover, this is only an average, for while $19 \%$ of Argentina emigrants are skilled workers, some $97.5 \%$ of Mexicans and Salvadorans are unskilled or low-skilled workers (Table 7). This mass immigration of unskilled workers meets the needs of industrialised countries, where widespread education has led the local population to abandon manual jobs and physical labour, which have low status. The contribution of foreign

Table 7. Share of skilled workers among Latin American emigrants: 1988-1995

\begin{tabular}{l|c|c|c}
\hline \multicolumn{1}{|c|}{ DESTINATION } & LATIN AMERICA & CANADA, ETATS-UNIS & TOTAL \\
\hline ORIGIN COUNTRY & 17.1 & 19.1 & 18.0 \\
\hline Argentina & 10.3 & 18.4 & 15.7 \\
Venezuela & 30.7 & 13.8 & 14.9 \\
Panama & 22.2 & 10.0 & 13.9 \\
Peru & 23.8 & 9.7 & 12.1 \\
Costa Rica & 21.6 & 10.9 & 11.2 \\
Cuba & 7.9 & 15.7 & 9.1 \\
Chile & 16.7 & 9.1 & 9.1 \\
Haiti & 8.9 & 9.4 & 9.0 \\
Uruguay & 8.1 & 12.0 & 8.7 \\
Bolivia & 8.6 & 6.9 & 7.2 \\
Equator & 5.6 & 8.8 & 6.6 \\
Colombia & 24.8 & 5.0 & 6.4 \\
Nicaragua & 12.4 & 4.5 & 5.5 \\
Honduras & 8.9 & 5.2 & 5.4 \\
Dominican Republic & 4.4 & 11.5 & 4.6 \\
Paraguay & 3.9 & & 3.9 \\
Brazil & 6.3 & 3.3 & 3.7 \\
Guatemala & 14.0 & 2.4 & 2.9 \\
Salvador & 16.3 & 2.6 & 2.7 \\
Mexico & 8.1 & 5.0 & 5.7 \\
Latin America & &
\end{tabular}

Note: Skilled workers contain holders of a University degree and vocational occupations.

Source: CELADE (2002). 
labour enables these countries not only to face a growing problem of a mismatch between labour supply and demand, but also to limit upward pressures on the wages of unskilled workers. Sending countries also benefit considerably from the emigration of unskilled labour, since the reduction in the number of job-seekers helps to relieve labour market pressures and thus prevent an overly sharp increase in unemployment.

Although there is great demand for foreign labour in industrialised countries, the demand is not limited to unskilled workers for there is currently a shortage of specialised workers in a number of sectors of activity, such as data processing and health care. This has created an opportunity for the best trained workers in developing countries, who can benefit from both better working conditions and much higher pay than in their own country. However, this brain drain, which enables the industrialised countries to attract the most highly-skilled workers from around the world, has at least two adverse effects for developing countries. Firstly, the brain drain reduces the human capital of the countries concerned, which slows down their progress. Because of the lack of opportunities in their own country, there are sometimes more highly skilled workers outside a given country than inside it. Adams (2003) has shown that there are 3.5 times as many skilled Jamaican workers in the United States as in Jamaica itself.

However, beyond the direct impact in terms of slowing down production and innovation, the emigration of skilled labour can have long-term repercussions on the educational level, since the incentive to invest in human capital diminishes if educated people leave their country to go work in the United States or Europe ${ }^{3}$. Consequently, this problem could, in the more or less long term, be detrimental to the educational efforts undertaken, which have already been affected by the budgetary adjustment policies implemented during the $1990 \mathrm{~s}$ in many Latin American countries. For example, Table 8 shows that there was a decline in the share of GDP devoted to public expenditure on education in 14 out of the 26 countries considered, between the 1980s and 1990s. Even though in many countries this decrease reflects a transfer of education to the private sector, this disengagement of a majority of Latin American countries nevertheless remains a cause for concern regarding the economic and social future of the region.

3 It should be pointed out that Beine, Docquier and Rapoport (2001) believe, on the contrary, that the brain drain can help raise the level of human capital in sending countries since it creates an incentive for people to prolong their education in order to take advantage of better job opportunities abroad. Since only a part of the skilled labour force will ultimately go abroad, the final result is superior to the situation prevailing before the brain drain. However, empirical tests show that the positive linkage between the emigration of skilled labour and higher investment in education is only valid in a limited number of cases. 
Table 8. Change in public expenditures for education: 1980-1999

\begin{tabular}{|c|c|c|c|}
\hline AVERAGE EXPENDITURE & $1980-1989$ & $1990-1999$ & TAUX DE CROISSANCE (\%) \\
\hline Mexico & 3.5 & 5.2 & 50.2 \\
\hline \multicolumn{4}{|c|}{ CENTRAL AMERICA } \\
\hline Barbados & 6.1 & \begin{tabular}{|l|l|}
7.4 \\
\end{tabular} & 20.1 \\
\hline Belize & 3.6 & 5.4 & 51.5 \\
\hline Costa Rica & 4.8 & 4.7 & -1.8 \\
\hline Cuba & 8.7 & 7.6 & -12.7 \\
\hline EI Salvador & 2.7 & 2.1 & -23.6 \\
\hline Guatemala & 1.7 & 1.7 & 0.8 \\
\hline Honduras & 4.0 & 3.6 & -10.3 \\
\hline Nicaragua & 4.7 & 4.5 & -4.4 \\
\hline Panama & 4.9 & 4.4 & -9.7 \\
\hline \multicolumn{4}{|c|}{ SOUTH AMERICA } \\
\hline Argentina & 2.5 & 3.6 & 43.8 \\
\hline Bolivia & 3.5 & 5.5 & 56.6 \\
\hline Brazil & 2.1 & 4.5 & 113.7 \\
\hline Chile & 3.7 & 3.3 & -12.1 \\
\hline Colombia & 2.9 & 3.7 & 28.0 \\
\hline Equator & 4.3 & 3.9 & -9.5 \\
\hline Paraguay & 1.2 & 2.9 & 154.1 \\
\hline Peru & 2.8 & 2.4 & -14.1 \\
\hline Uruguay & 1.9 & 2.7 & 45.3 \\
\hline Venezuela & 4.3 & 4.0 & -5.7 \\
\hline \multicolumn{4}{|c|}{ CARIBBEAN } \\
\hline Haiti & 1.4 & 1.9 & 36.7 \\
\hline Jamaica & 3.6 & 6.5 & 79.1 \\
\hline Dominican Republic & 1.9 & 1.8 & -6.7 \\
\hline Saint Kitts and Nevis & 6.3 & 3.9 & -38.9 \\
\hline Surinam & 5.1 & 3.6 & -29.7 \\
\hline Trinity and Tobago & 4.3 & 3.6 & -15.3 \\
\hline
\end{tabular}

Note: Public expenditures for education are stated in percentage of the GDP. Source: CEPAL (2005).

It should be pointed out, however, that skilled Latin American workers mainly immigrate to other countries within the region, where the competition is less intense, while unskilled workers tend to go to the United States or Canada (Table 7). Although the impact of the brain drain should not be minimised, it should not be exaggerated either, for not all skilled workers leave the region and the investment in human capital is not lost entirely. Nonetheless, one of the challenges facing Latin American governments in the future will reside in their capacity either to retain the most skilled workers in their country, which will not be easy given the wage differential between Latin America and industrialised countries, or to promote the return of emigrants to their home country. The latter solution is more realistic and beneficial than the former. It is more realistic because Latin American expatriates who have accumulated sufficient savings may wish, after spending some 
Figure 1. Social expenditures and emigration rates: 1990-1999

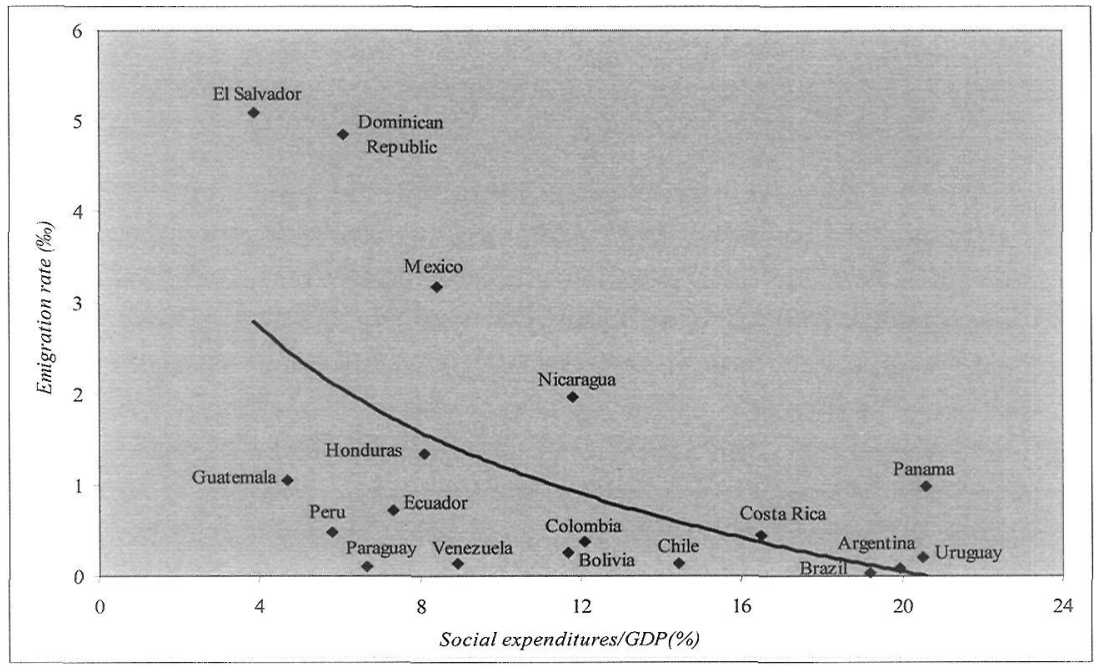

Note: Social expenditures include public expenditures for education, health, social security and housing. They are stated in percentage of the GDP. Emigration rate = (immigrants in the United States/population) $\times 1000$. Correlation coefficient $=-0,51$.

Sources: Immigration to the United States: U.S. Department of Homeland Security (several years); population and social expenditures: CEPAL (2005).

\section{Figure 2. Official development assistance, foreign direct investment and remittances in Latin America: 1990, 2000 and 2003}

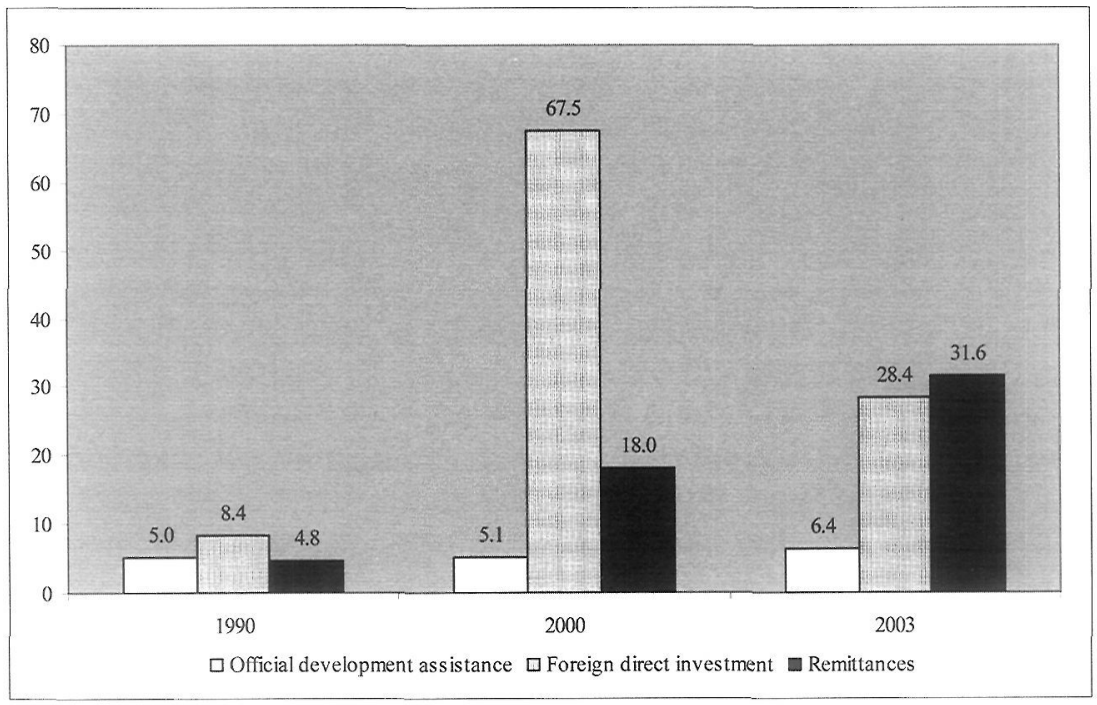

Note: In billions dollars.

Sources: Official development assistance: World Bank (2005); Foreign direct investment: CEPAL (2005); Remittances: IMF (2005) 
years or even decades abroad, to return home and enjoy a standard of living that they might not have in the United States or Europe. And it would be more beneficial since the investments made by these former emigrants and the experience and skills that they have acquired abroad would promote the accumulation of both financial and human capital. It is in this perspective that "brain circulation" may be an asset for the development of Latin America in the future. However, this scenario is based on a number of favourable assumptions, such as migrants' desire to return home, which seriously limit its validity.

\section{CONCLUSION: WHAT IS THE RESPONSIBILITY OF LATIN AMERICAN GOVERNMENTS?}

The high rates of emigration in Latin America today are one of the most tangible signs of the failure of economic and social development strategies in the region. The process of catching up has been completely stalled or even reversed by the import substitution policies implemented in the 1950s in most Latin American countries, while the opening up of economies to international competition in the mid-1980s has affected the least skilled members of the labour force, who have often had no other option but to emigrate because of rising unemployment. Moreover, it is by no means certain that the mass emigration process is helping the development of Latin American economies. The beneficial effects of remittances on consumption and possibly on savings may not be able to offset the costs associated with the loss of competitiveness generated by overvalued exchange rates, insufficient productive investment and above all the deterioration of human capital. This is all the more true given that the safety valve provided by emigration to some extent allows Latin American governments not to face up to their responsibilities, since it enables them to avoid making the decisions that are nevertheless required to fight unemployment and poverty. This is not only because migrants help reduce labour market tensions by leaving the country, but they also provide for the social protection of their families through their remittances. They also act as a substitute for government by reducing inequalities since it is generally the poorest families that benefit from this extra income. Consequently, there is an implicit incentive for Latin American governments to encourage emigration. It is to be feared that the failure of governments to face up to their economic and social responsibilities will handicap Latin American economies in the very long term and further increase the outflow of migrants for many years to come. 


\section{REFERENCES}

ADAMS, R. (2003). "Internacional Migration, Remittances, and the Brain Drain: A Study of 24 Labor-Exporting Countries." World Bank Policy Research Working Paper 3069.

BEINE, M.; DOCQUIER, F. and RAPOPORT, H. (2001). "Brain Drain and Economic Growth: Theory and Evidence." Journal of Development Economics 64.1:275-89.

BHAGWATI, J. (2004). In Defense of Globalization. New York: Oxford University Press.

CARRINGTON, W. and DETRAGIACHE, E. (1998). "How Big is the Brain Drain?" IMF Working Paper WP/98/102.

CELADE - Centro Latinoamericano y Caribeño de Demografia (2002). La migración internacional y el desarrollo en las Américas. Santiago de Chile: CEPAL, United Nations.

CEPAL - Comisión Económica para América Latina y el Caribe (2005). Bases de Datos en Línea. Santiago de Chile.

CEPAL - Comisión Económica para América Latina y el Caribe (2004). "Explosivo aumento en remesas que emigrantes latinoamericanos envían a sus familias de origen." Notas de la CEPAL. 33: 1-3.

CEPAL - Comisión Económica para América Latina y el Caribe (2002). "La migración internacional y la globalización." Globalización y desarrollo. Santiago de Chile: Naciones Unidas: 243-273.

CLARK, X.; HATTON, T. and JEFFREY, W. (2003). "What explains Cross-Border Migration in Latin America?" Harvard Institute of Economic Research Discussion Paper 2012.

DNP - Departamento Nacional de Planeación (1998). La paz: El desafio para el desarrollo. Bogotá: Tercer Mundo Editores.

HATTON, T. and JEFFREY, W. (1998). The Age of Mass Migration: Causes and Economic Impact. New York: Oxford University Press.

IMF - International Monetary Fund (2004). Balance of Payments Statistics Yearbook, 2004. Washington, D.C.

KHOUDOUR-CASTÉRAS, D. (2005). "Welfare State and Labor Mobility: The Impact of Bismarck's Social Legislation on German Emigration before World War I." Mimeo, University of California, Berkeley.

KHOUDOUR-CASTÉRAS, D. (2004). "Exchange Rate Regimes and Labor Mobility: The Key Role of International Migration in the Adjustment Process of the Classical Gold Standard." Mimeo, University of California, Berkeley.

PERDOMO, R. (1999). Impacto socioeconómico de las remesas: perspectiva global para una orientación productiva de las remesas en Honduras. México, D.F.: CEPAL.

SÁNCHEZ-ALONSO, B. (2000). "European emigration in the late nineteenth century: the paradoxical case of Spain." Economic History Review 53.2: 309-330.

SOLIMANO, A. (2003). "Globalización y migración internacional: la experiencia latinoamericana." Revista de la CEPAL 80: 55-72.

UNDP - United Nation Development Program (2005). Human Development Report, 2004. New York.

U.S. Department of Homeland Security (2004). Yearbook of Immigration Statistics, 2003. U.S. Government Printing Office: Washington, D.C.

World Bank (2005). World Development Indicators, 2004. Washington, D.C. 